\title{
The Right to Information and Societal Accountability: The Case of the Delhi PDS Campaign
}

\author{
Suchi Pande
}

\begin{abstract}
1 Introduction
Many development scholars in India see the recently enacted the Right to Information (RTI) as a tool to ensure transparency and accountability in the day-today functioning of government. The poor so far have been denied basic rights and necessities 'through a web of lies based on information that is quoted but never revealed' (Roy et al. 2006). In this context, legal tools like the RTI and other supporting mechanisms, such as public hearings and public audits, have 'eroded the social acceptability of corruption' (Roy et al. 2007). The RTI has emerged centre-stage in societal actors' demands for direct accountability.
\end{abstract}

In this article, the question I seek to answer is: How and to what extent can tools like the RTI be a means of ensuring transparency and accountability? A related question is: Does the RTI have the potential to be a tool for collective action by poor people? These questions are important because ensuring accountability seems to be key to improving governance as well as service delivery (World Bank 2003). Yet there is a lack of analytical debate on the use of RTI as an alternative mechanism of ensuring accountability by societal actors. On the one hand, there has been an enthusiastic portrayal of RTI as a tool to ensure accountability, not simply through the provisioning of information alone, but as precursor to supporting mechanisms like public hearings and public audits (Roy et al. 2006, 2007). On the other hand, some are increasingly questioning the portrayal of RTI as 'a magic wand' and the extent of success it is able to deliver. ${ }^{1}$ Others have also expressed doubts over the use of RTI by the poor and marginalised groups due to the complexity of the legal process involved.?
Recently there has also been a debate about the capacity of poorer groups to represent themselves and make claims on the government. Some scholars argue that poorer groups have limited capacity to (collectively) represent their claims, or to present a policy or reform agenda that would address issues of basic rights, which explains why they have to rely either on 'self-provisioning' or on elected political representatives for the same (Harriss 2005). Others also argue that India's 'otherwise vibrant and diversified' civil society has been 'unsuccessful' in combating 'forms of corruption' that 'disproportionately afflict the poor' (Jenkins and Goetz 2003). The question for this article then is: to what extent can the RTI be used to advance the claims of the poor and make government accountable?

In the following sections, I attempt to address some of these concerns with the RTI. I argue that a set of activists have used the RTI successfully to mobilise poor people and used information to generate awareness through the media, as a way of making government accountable. To make this argument, I use the case of Parivartan, a Delhi-based citizens group working on issues of corruption and accountability. Parivartan has spearheaded the use of RTI as a tool to expose corruption in governmentrun programmes in urban areas.

In 2001, Parivartan mobilised residents of lowincome residential settlements, slums and squatter settlements and made use of the Delhi Right to Information Act (RTI) to access information on the implementation of the Public Distribution System (PDS), a government programme for ensuring basic food-grains at affordable prices for the poor. The 
RTI-based records exposed the diversion of foodgrains taking place. Simultaneously, Parivartan was able to get the system of public scrutiny of PDS records institutionalised through collective social action and the support of sympathetic bureaucrats.

This article is based on fieldwork conducted in 2003-5, as part of the Delhi PDS Campaign. The article also relies on series of interviews conducted in 2006-7 with academics, government officials and activists, as well as primary and secondary data available on the PDS. The article continues with two main sections: Section 2 begins with a literature review on accountability in Delhi. The aim of this section is to situate the Parivartan case and the use of RTI in the debates around different types of accountability: horizontal, vertical and/or societal. Section 3 will outline the history of the PDS: programme inception in the 1970s, the change in policy since 1990 onwards, and a summary of the main debates around this change; followed by a detailed analysis of the Delhi PDS Campaign with the focus on Parivartan. This is followed by the conclusions.

\section{Accountability and associational activity in Delh} In this article, I limit my discussion on accountability to Schedler's (1999) concepts of 'answerability' and 'enforceability'. Through the use of RTI, information that should ordinarily be available, became accessible. But what are the implications of disclosure of such information? Such disclosure allows citizens to take steps against public agency's actions that are deemed unacceptable, such as diversion of food designated for the poor. Further action in the form of enforcement against the defaulting agencies requires more than traditional mechanisms of 'enforceability' - 'sanctioning authorities'. To bring about the institutionalisation of effective mechanisms of enforceability requires consistent demands by organised social actors. Social mobilisation is not easy, and RTI by itself does not enable collective action, it does however create an enabling environment for mobilisation. The Parivartan case discussed in Section 3 will show that in the context where traditional mechanisms of accountability can be ineffective and insufficient, a movement for new forms of 'societal accountability' can be successful and, under certain circumstances, institutionalised.

\subsection{Forms of accountability}

For democracy to function effectively, it is necessary that the institutions and its representatives that are entrusted with the task of maintaining the checks and balance do so effectively. Therefore, it is essential that effective accountability mechanisms are put in place to check the misuse of power by government agencies and their representatives. Focusing on such mechanisms of preventing and redressing the misuse of power by government agencies and public officials, Schedler (1999) defines accountability as the 'twodimensional concept' of 'answerability' (public officials are answerable for or must explain their actions) and 'enforceability' (any action of a public official can be called into question and punished for any act of omission or commission by a sanctioning authority).

Traditional mechanisms of accountability seem to encounter numerous problems and stumbling blocks at different levels of government agencies. Organisation of bureaucracy renders accountability mechanisms inefficient for several reasons:

- Complicity between higher and lower levels of government makes it difficult for the 'answerability' and 'enforceability' concept to have the desired monitoring effect.

- Very often there is no way of effectively ensuring that the 'sanctioning authority' can function independently and actually punish erring public officials.

- Mechanisms adopted by sanctioning authorities, like vigilance committees, grievance redressal cells, etc., are not time bound and can be easily manipulated by vested interests.

The mechanisms of accountability existing within the institution of elected representatives are also highly inefficient because:

- Despite being free and fair, elections are generally lacking of issue-based platforms.

- Every five years, citizens are able to hold 'elected' officials accountable, but due to limitations of time, citizens are unable to call back elected representatives if they fail to deliver on their promises.

This article argues that the traditional mechanisms of accountability are proving to be insufficient in certain contexts, and therefore new mechanisms of 'societal accountability' are becoming popular among social movements. Through such mechanisms, social movements can carry out campaigns, build public opinion and put pressure on elected governments to 
face the issue and to duly respond to the citizens' demands. 'Societal accountability' is another form of vertical accountability; it is non-electoral yet vertical, involving citizen associations, social movements and the media with diverse strategies: (1) to monitor government functioning and actions of public officials; (2) to expose wrongdoings of the government; and (3) to activate horizontal accountability agencies (Peruzzotti and Smulovitz 2006; Smulovitz and Peruzzotti 2000).

Peruzzotti and Smulovitz (2006) argue that societal accountability is 'activated on demand', applying both institutional tools (such as legal action) as well as non-institutional tools (such as social mobilisation, media exposure) to achieve its objectives. This proaccountability mechanism, they argue, compensates for the built-in deficits in the traditional mechanisms (Smulovitz and Peruzzotti 2000). Actors using societal accountability mechanisms perform watchdog functions; they rely on the 'intensity of their claims' and on the impact on public opinion. Public exposure incurs 'reputational costs' and helps in putting things on the public agenda, consequently making the 'administration more responsive to societal needs'. One of the limitations of societal accountability has been its ability to impose 'symbolic sanctions' and not have 'mandatory affects' (Peruzzotti and Smulovitz 2006). As Mainwaring (2003) puts it: accountability 'cannot exist with no sanctioning power'. Yet Peruzzotti and Smulovitz (2006) claim that the intensity and visibility of voice through 'symbolic sanctions' can have 'material consequences'; therefore it is unfair to dismiss societal accountability mechanisms altogether. Societal accountability operates in a decentralised, piecemeal manner, with varied purposes and varied tools, and with a focus on policies or politicians whom societal actors seek to control.

\subsection{Representation, associational activity and the urban poor in Delhi}

Studies on civil society in India tend to agree that Delhi offers a particularly barren landscape with a few active organisations to speak. Those that do exist have few links to poor communities (Houtzager et al. 2002; Harriss 2005).

Recent studies on participation by and representation of the urban poor vis-a-vis service provisioning suggest a kind of reluctance on the part of the government to improve the access of the poor to basic services. One study argues that 'it is unclear whether the needs being highlighted genuinely reflect the priorities of slum residents, or ... get inadvertently replaced or otherwise by the priorities of Government or NGOs, in a hurry to show results' (Pande and Sudarshan 2007). Houtzager et al. (2002) argue that traditional forms of political representation available to the poor through trade unions and political parties that were 'concerned with the achievement of social and economic rights' are now being replaced by emerging new patterns based on 'other sorts of social networks and goals'.

Yet, other studies point towards a possible 'decline of state responsiveness to social claims'. Under such conditions the poor either engage in 'selfprovisioning' or rely on political parties and their representatives to access services or redress grievances (Harriss 2005). A recent study in Delhi concludes that, despite a high level of collective action in Delhi, the poor still most commonly chose to approach political parties to represent themselves and to tackle their problems. And 'there is little indication, in fact, of the existence of any other significant collective actions in the worlds of poor people'. The same study also argues that there is an evidence of 'informal collective action' with the poor engaging in 'self-provisioning', and 'collectively' solving problems through their friends, families and neighbours (Harriss 2005). Pande and Sudarshan (2007) speak of 'need-based negotiations', where the poor rely heavily on political representatives as the initial forum for redressal or service provisioning. It appears therefore, that in India as a whole, the needs and interests of the poor are now being met more effectively through the 'new politics' of social movements, rather than trade union, burgeoning non-governmental organisations (NGOs), associations of civil society, or indeed political parties.

\section{The PDS in India}

The PDS is India's national food security programme; ${ }^{3}$ one of its many objectives is to make subsidised food-grains, along with sugar and kerosene oil, available to families 'below the poverty line' (BPL). Government-run and managed, the PDS performs two main functions:

- maintaining price of grains stability, through the implementation of a minimum support price paid to farmers 
- making available grains, such as wheat and rice, as well as other commodities, like sugar and kerosene oil, to food-grain cardholders.

Under PDS, there are three types of cardholders ${ }^{4}$ that are serviced at subsidised rates.

Since the Second World War, the PDS evolved from a wartime food-graining system, started by the British, to a welfare measure in 1950 with the onset of planning. When it was started, the PDS was implemented largely in urban areas with limited extension to rural areas (only those rural areas that are considered to have food deficit get included in the programme). Later crop failures, food shortages, price fluctuations and the droughts of 1965-6 and 1966-7 led to the expansion of the PDS into a universal access programme (Swaminathan 2000). Between the 1970s and 1990s, the PDS was viewed as a component of the government's strategy to alleviate poverty. The growth of domestic agricultural production allowed for further expansion of the PDS, as well as other food-for-work type of employment programmes. The network of fair price shops ${ }^{5}$ grew, and special schemes to supply food for the poor were also introduced (Swaminathan 2000). But the gap between the policy design and its actual implementation on the ground has been a subject of debate for over a decade.

According to Kabra and Ittyerah (1992), there were several problems with the PDS. The levels of supplies of food-grains under the PDS at times were not adequate to keep the fair price shops well stocked and to replenish commodities. As a result, consumers were 'unable to look forward to regular supplies through the PDS channels'. Further, entitlements provided under the PDS were lower than the consumption levels warranted on the basis of nutritional norms, since the PDS was aimed at providing the 'essential', not 'total', consumption level of the poor. The PDS supplies also reached the fair price shops late, thereby giving the shop owners a 'ready alibi' for their inability to supply the cardholders according to their entitlements.

Kabra and Ittyerah (1992) also argue that 'universal coverage often reduces the entitled scale and availability to such an extent, that a large section of consumers voluntarily exclude themselves from the system'. Large-scale voluntary exclusion by the 'relatively better off' and 'vocal' section of the population provides 'ideal conditions for the diversion of PDS supplies'. This not only results in reducing access for the poor, but also in their 'involuntary exclusion due to large scale diversion' (Kabra and Ittyerah 1992). The PDS was criticised for its inability to serve the poorer population, 'urban bias', negligible coverage in parts of the country populated predominantly by the rural poor, and lack of transparent and accountable arrangements for delivery (Planning Commission of India 2007).

Since the beginning of the 1990s, two major changes have been introduced in the PDS: the Revised PDS (RPDS) and the Targeted PDS (TPDS). This article focuses on the second major change. In 1997, the government introduced a new programme with a focus on the poor with income-based targeting - the TPDS. The TPDS was an attempt to target households using an income criterion (using the income poverty line to demarcate 'poor' and 'non-poor' households) with the objective of streamlining the PDS. The programme was designed around provisioning of basic goods, such as foodgrains, sugar and kerosene oil on a dual pricing basis. A two-tier card system was introduced in order to represent a distinction between above and below poverty line cardholders.

This change from a universal access system to a targeted programme generated a series of debates around such issues as: abilities of the poor to access PDS, corruption and lack of accountability in the delivery system, and problems with identifying and servicing BPL households. Some scholars argued that targeting was a direct result of the International Monetary Fund (IMF) promoted structural adjustment programmes, which India began following after the economic liberalisation of the 1990s (Swaminathan 2000).

The government's main argument for introducing targeting was the reduction of the food subsidy budget, which was achieved through a rise in the central issue price (CIP) ${ }^{6}$ under the TPDS. After a series of debates within the coalition partners, the government reached a compromise to marginally enhance the CIP and make $10 \mathrm{~kg}$ of wheat and rice available to the BPL households at subsidised rates. The move was criticised and seen as a weakening of the PDS, which was considered to act as a social safety net for the poor (Muralidharan and Mahalingam 1997). It was argued that $10 \mathrm{~kg}$ per household was far 
below the total household requirement of $30 \mathrm{~kg}$, and therefore the poor would inevitably end up buying the remaining quantity in the open market, thus defeating the purpose of targeting. Some authors claimed that 'for all the agitation over the food subsidy burden entailed by the TPDS, its actual benefit to the poor was no more than marginal' (Muralidharan and Mahalingam 1997).

Other criticisms of the policy change were the continual inability to address problems of access by the poor, by not ensuring that the poor could access their food-grain quota in instalments (even though provisions for this do exist under the TPDS) (Jishnu 2004). Further, the TPDS had no inbuilt measures to ensure that the deserving households benefited from the programme; and there have been serious errors with setting the income criterion and identification of BPL families by state governments. As a result, several deserving households have not been issued $\mathrm{BPL}$ cards because a certain section of the population - 'destitute households' - tends to remain 'socially invisible' from most development programmes and welfare schemes. According to Dreze, the PDS became 'largely a mechanism of disposing of surplus grains' rather than addressing 'issues of chronic poverty, malnutrition, starvation and hunger' (Jishnu 2004).

Even at present, the real situation on the ground is far from the TPDS as envisaged, reflecting huge gaps in the implementation of the programme. It has been argued that the introduction of targeting not only left the initial set of PDS problems unresolved, but might have further exacerbated them. Targeting the PDS to a section of the population 'below the poverty line' has brought about both inclusion and exclusion errors: those deserving have been left out, and those that were better placed to exploit the system have gained access (Swaminathan 2000).

In 2001, the dysfunctional PDS became a subject of national debate, as people in parts of India died of starvation and hunger, while approximately 50 million tons of food-grains were rotting in the Food Corporation of India godowns (stores). A group of activists filed a Public Interest Litigation (PIL) against the Government of India, and soon afterwards a national network of campaigns by organisations and individuals came together to form the Right to Food Campaign $(2005)^{7}$ that took forward the issues of food security, malnutrition, starvation, and women's and children's food security. In Delhi, the RTI prompted a two-year-long campaign that took up the issue of corruption within the PDS. The next part of this section discusses the Delhi PDS Campaign in more detail.

\subsection{Parivartan: a citizen's collective against corruption}

Parivartan, by its own definition a 'people's movement against corruption', is an urban grassroots organisation; six of its permanent working group members are residents of a low-income neighbourhood in east Delhi. Nine members constitute a permanent working group along with an informal group of like-minded people who work as volunteers. Parivartan distinguishes itself from conventional NGOs in that it accepts no institutional funding (external or from within India) and does not focus on service delivery. Parivartan's organisational form and ideology are close to another prominent grassroots organisation, the Mazdoor Kisan Shakti Sangathana (MKSS) from which it draws inspiration. ${ }^{8}$

The MKSS has pioneered the cause of transparency and accountability in government functioning since the late 1980s. It developed a political platform for the rural poor and challenged the educated elite's perception of the poor as being illiterate and therefore inarticulate. The RTI movement in India has been led by the MKSS working with the poor farmers, workers and villagers. The MKSS was central to shaping the movement's discourse based on the concept of transparency as related to truth, openness and closely linked to basic survival and livelihood. Parivartan used a number of MKSS's strategies of accessing information, organising public hearings and carrying out public audits. However, the focus of Parivartan campaigns shifted from the issues of transparency to the issues of accountability and corruption in government functioning.

Parivartan used the MKSS highly successful model of jan sunwais, or public hearings, which involves three stages:

- accessing information

- collectively analysing official information

- verifying the information through a process of public hearings.

These hearings are presided over by an independent panel and involve citizens, as well as government 
officials. Through this process of social/public audit, a demystification of information previously considered secret takes place and information is read out aloud and in public, so that people can check for discrepancies. For example, in some instances, people found that government records showed they had been accessing the PDS continuously, when in fact they each time cardholders had gone to access the grains they were entitled to, the shop had been closed. As Jenkins and Goetz (2003) argue, 'this approach depends on the principle of collective and very local verification of official accounts, as it is only at the local level that the many small diversions of funds, which go unnoticed in massive formal audits, can be detected'.

When the MKSS began using jan sunwais to expose corruption in number of localities, access to information was extremely difficult in the absence of the RTI. In Parivartan's case, the task of using jan sunwais was made easier because of the Delhi RTI, which enabled access to official records.

\subsection{The Delhi PDS Campaign}

In 2002-3 Parivartan was working in a small lowincome settlement in east Delhi. Triveni, a lowincome resident of the settlement, came to Parivartan with the complaint that she had been unable to obtain her entitled food-grains from the PDS shop for the last three months and wanted to know what she could do. She was advised to file an application under the RTI requesting copies of all PDS records, including cash memos. Before the information could arrive, Triveni was offered Rs.20,000 and sacks of grain by the PDS shop owner; if she took back her RTI application. Triveni refused both the money and the sacks of grain, and persisted with her RTI application. When the information arrived, Triveni was shocked to learn that, as per government records, she had been getting grain from the PDS shop for the last three months. Triveni is literate and can sign her own name, so she was outraged to see thumbprints of varying shapes and sizes against her name in the cash memos, so she decided to file a complaint with the Food and Civil Supplies Department. ${ }^{9}$

Simultaneously, using the RTI, Parivartan accessed records for all fair price shops in that area and began to analyse the information. Using the information revealed in Triveni's case, Parivartan started mobilising neighbourhood residents; Triveni herself became active in Parivartan. The media too became interested and reported Triveni's case; she was even called for a television interview.

In August 2003, Parivartan organised a jan sunwai and over 300 people from across Delhi filed RTI applications to view their food-grain records. The fair price shop owners were legally obligated to disclose information, but they managed to obtain a stay order from Delhi High Court, which in effect prohibited Parivartan access to fair price shop records. It was then argued that, although Parivartan was under the stay order, for the remaining applicants the right to view their records was not affected. Inspection of official records began; applicants were assisted by Parivartan volunteers in inspecting files and in retrieving copies of documents/records. At the same time, Parivartan started to expand their campaign, reaching out to other slums and low-income settlements, in order to find out the status of the PDS in those settlements, to mobilise residents and to generate awareness on the use of RTI.

As the campaign spread, there were reports of violence against Parivartan's volunteers, as well as against applicants: there were incidents of physical violence, and people were threatened and bribed, compelled and cajoled to take back their RTI applications. Some people withdrew, but many did not. Those who accessed information reported a marked change in the attitudes of the fair price shop owners.

By mid-December 2003, Parivartan had managed to access information on fair price shops and kerosene oil depots for the three settlements where it had begun working intensively on the PDS issue. Information from daily sale registers, stock position registers, and copies of cash memos were analysed, collated and a verification exercise was undertaken. Out of the 182 families surveyed, 142 families did not receive a single grain of wheat and 167 families did not receive rice during the month of June 2003. A total of 87 per cent of wheat and 94 per cent of rice under the PDS had been diverted and sold in the open market.

Soon the association of fair price shop owners approached Parivartan with their concerns. They also approached the local elected representative with a plea to speak to the government and to lobby for the increase in their commission under the PDS, because the existing rate of commission for the shop owners was too low to make any profit. 
In March 2004, another verification exercise was undertaken in another locality in east Delhi. The 82 families surveyed were informed that there was an improvement in delivery of grains under the PDS. The effects of the PDS Campaign were felt in different parts of the city, but two near fatal attacks on Parivartan's youngest member demonstrated both the real power of the campaign, as well as the risks involved in challenging organised networks of corruption.

These attacks led to an announcement by the residents that they would boycott a month's quota of food-grain and kerosene oil. The residents' boycott included demands to access and to inspect their food-grain records in the Food Commissioner of Delhi's office. They also wanted a clear commitment from the Commissioner that if discrepancies were to be found, then immediate action would be taken against defaulting shop owners and government officials. Throughout February 2005, fair price shop owners individually approached cardholders, requesting them to take their grains, shops remained open at designated times, and the local government officials carried out periodical inspections, in some instances with video cameras. At the end of the month, an inspection of records revealed no discrepancies.

This led Parivartan to push for institutionalising the system of public scrutiny of records. The Food Commissioner, sympathetic to the demands of public scrutiny of records, initiated the process on a pilot basis in the areas where Parivartan was active. Within a short period of time, it was scaled-up to apply to all food and supply circles across Delhi. Two Saturdays of every month were designated for public viewing of food-grain records and for lodging complaints. In the first few months of operationalisation, five shop owners were suspended in the east district of Delhi, and a district level officer was issued a suspension letter, on the eve of his retirement, informing him that an inquiry was opened against the functioning of his circle office.

\section{Conclusions}

The case of Parivartan is significant for two reasons. First, although the PDS Campaign in Delhi spearheaded by Parivartan has not been able to reform the entire system of distribution and delivery under the PDS, it has however put Parivartan in a position where it is now able to enter negotiations around pubic policy. The process of disclosure of information through the RTI also 'establishes a dialogic relationship between the accountable and the accounting actors'. It makes both parties speak and engages them both in public debate. To reach this stage of debate or negotiation is only possible once both parties are on an equal footing. This is a form of 'direct relations' that allows a form of 'societal accountability', which seeks to ensure that government meets its affirmative duty to act (Houtzager et al. 2006). Such 'direct relations', it is argued, are possible when citizens have 'sufficient legal and effective equality in their interaction with public officials'. The use of RTI in the PDS in Delhi demonstrates that with access to information, citizens can begin to chip away at the inequality in relations between classes and the government.

Second, it also highlights the potential for grassroots organisations like the MKSS and Parivartan, in combating corruption that directly affects the poor.

The use of RTI implies taking a confrontationist stance against the government and Parivartan has been able to do it successfully because it is neither dependent on the government's goodwill, nor in any way vulnerable to intimidation, as it accepts no foreign funding. Moreover, it is important to note that the bureaucracy was supportive because the Parivartan campaign was primarily directed against the fair price shop owners, ${ }^{10}$ i.e. private actors separate from the government. It might have been harder to find support within the bureaucracy, had its own lower levels been directly implicated in the corruption.

Further, the PDS was not an arena of interest for politicians for several reasons. ${ }^{11}$ Given the administrative structure of the PDS and its functioning in Delhi, elected representatives have no influence over the administration of PDS, or over the distribution or delivery of food-grains. Elected representatives seem to have some control and influence in the issue of licences for running ration shops and kerosene oil depots under the PDS, for which they may even receive a share of the profit. But perhaps it is precisely such disinterest on the part of local representatives that created an opportunity for Parivartan to campaign over the issues that did not threaten them. The extent to which they would allow NGOs to take over areas that fall under their jurisdiction, and thus might challenge their politics of patronage (such as 
aforementioned issues of access to water, sanitation, refuse collection), is an open question.

In conclusion, it appears that the combination of Parivartan (a dedicated grassroots activist organisation) and the RTI was necessary for the successful exercise of societal accountability: each alone would not have been sufficient to achieve the results that they did. The government's role in creating spaces for social actors/groups to participate was critical. In the PDS Campaign, a sensitive bureaucracy was the third element that enabled Parivartan and the residents of the settlement to produce the results.

The PDS Campaign has made only a small dent in a larger system, which continues to be unfair and unequal. In the long run, it is important to note that there are still issues with the PDS that need to be addressed. For example, the fair price shop owners have no way of making money if they do not resort to corruption, as the commission paid by the government is simply not enough for survival. The problems of access, errors of inclusion of non-poor groups and exclusion of poor groups, corruption and mismanagement are still prevalent in the PDS. But the use of RTI has shown a way of dealing with these problems. The real question is whether institutionalisation can contribute to the development of grassroots activism on a larger scale - by other organisations in other localities? So far, the signs are positive, but progress is slow. Following the Parivartan experience, an organisation called Satark Nagrik Sangathan (SNS) ${ }^{12}$ is carrying out similar work in low-income settlements in the south district of Delhi. Recently, another organisation in the west and north-west district of Delhi assisted 100 slum-dwellers to file RTI applications to find out why they were being denied their quota of foodgrains, despite holding valid cards.

\section{Notes}

1 Comments made by participants at the IDS Project 'Modes of Collective Action, Service Delivery and Societal Regulation', New Delhi, 1-2 March 2007.

2 Ibid.

3 The Food Corporation of India (FCl) set up in 1964 under the jurisdiction of the Department of Food and Civil Supplies, is the sole central implementing agency in charge of procurement, storage, transport and distribution of food commodities. State governments purchase the commodities required for distribution from the $\mathrm{FCl}$ and make them available to the fair price shops for distribution to cardholders. There is a large network of fair price shops across the country in both rural and urban areas. They are licensed by the government and are privately owned. The State Food and Civil Supplies department in each state is responsible for implementing, monitoring and enforcing legal provisions relating to delivery of food commodities.

4 Depending on the card, each household is entitled to $35 \mathrm{~kg}$ of wheat and rice and $1,200 \mathrm{~g}$ of sugar per unit (unit = family member whose name is displayed on the card). The three types of cards under the PDS are, above poverty line ( $\mathrm{APL}$ ), below poverty line (BPL) and Antodaya Anna Yojana (AAY); in 2000, the AAY was introduced under the TPDS as a subcategory to BPL. The

APL cardholders are issued grains at a price closer to the market rate, while the BPL and AAY cardholders receive the same quality/quantity of grains, at a subsidised rate, in which the AAY is further subsidised (at Rs.2/kg for wheat and Rs. 3/kg for rice). The AAY is a scheme under the TPDS targeted to the poorest of the poor; to 'provide food-based assistance to destitute households'; and other items are accessed at further subsidised rates for BPL cardholders.

5 Also known as ration shops; these are privately owned, with the responsibility of distributing grains, sugar and kerosene oil. Licenses for running a ration shop or a kerosene oil depot is issued by the government.

6 The prices at which the Food Corporation of India (FCl) sells grain for the PDS to State governments.

7 A Brief Introduction to the Campaign, www.righttofoodindia.org/campaign/campaign.htm

8 The MKSS is a grassroots organisation of mainly poor people based in Rajasthan's economically underdeveloped Rajsamand district. The MKSS has been crucial to the passage of the RTI in India. Its interest in the RTI arose from its work in the late 1980s and early 1990s on livelihood issues, particularly the failure of the state government to enforce minimum-wage regulations on employment-generation programmes in droughtprone areas. This generated belief that access to 
official documents was an essential part of the struggle to demand accountability from local authorities (Jenkins and Goetz 2003).

9 The nodal department in the Delhi government, in charge of implementing the PDS in Delhi.

10 The delivery of sugar and kerosene oil under the PDS takes place through a network of fair price shops (FPS) and kerosene oil depots (KOD).

11 In fact, it is the fair price shop owners who approached the elected representatives to

\section{References}

Harriss, John (2005) Middle Class Activism and Poor People's Politics: An Exploration of Civil Society in Chennai, Working Paper Series, Development Studies Institute, London School of Economics

Houtzager, Peter; Acharya, Arnab and Gurza Lavalle, Adrián (2006) Associations and the Exercise of Citizenship in New Democracies, Evidence from São Paulo and Mexico City, IDS Working Paper 285, Brighton: IDS

Houtzager, Peter; Collier, Ruth Bernis; Harriss, John and Gurza Lavalle, Adrián (2002) Rights, Representation and the Poor: Comparisons Across Latin America and India, Working Paper Series, Development Studies Institute, London School of Economics

Jenkins, Rob and Goetz, Ann Marie (2003) 'Bias and Capture. Corruption, Poverty and Limitations of Civil Society in India', in Marc Blecher and Robert Benewick (eds), Asian Politics in Development, London: Frank Cass: 109-22

Jishnu, Latha (2004) 'Too Little on the Plate', Businessworld, 28 July, www.businessworld.in/ july2604/indepth03.asp (accessed 14 March 2007)

Kabra, Nayan Kamal and Ittyerah, Chandy Anil (1992) The Public Distribution System in India, New Delhi: Eastern Books

Mainwaring, Scott (2003) 'Introduction: Democratic Accountability in Latin America', in Scott Mainwaring and Christopher Welna (eds), Democratic Accountability in Latin America, Oxford: Oxford University Press

Muralidharan, Sukumar and Mahalingam, Sudha (1997) 'Weakening Welfare: The Public Distribution Mess', The Frontline 14.21: 18-31

Pande, Suchi and Sudarshan, Ratna M. (2007) 'Ensuring Public Accountability Through Community Action: A Review of the Project', in Ratna M. Sudarshan and Suchi Pande (eds), influence bureaucrats, as was evident in the Parivartan case - to first get a stay order from the Delhi High Court barring inspection of official records, and then to seek audience with the Delhi State Food Minister, through the regional Party head, to complain about Parivartan.

12 SNS means Vigilant Citizens' Collective. SNS works in a slum settlement in South Delhi and actively uses RTI in matters related to the PDS and other services for the poor.

Ensuring Public Accountability Through Community Action: A Case Study in East Delhi, New Delhi: Institute of Social Studies Trust: 20-53

Peruzzotti, Enrique and Smulovitz, Catalina (2006) 'Social Accountability: An Introduction', in Enrique Peruzzotti and Catalina Smulovitz (eds), Enforcing the Rule of Law: Social Accountability in the New Latin American Democracies, Pittsburg: University of Pittsburg Press

Planning Commission of India (2007) 'The Public Distribution System', in Tenth Five Year Plan 2002-07, Ch. 3.4: 368, www. planningcommission.nic.in

Right to Food Campaign (2005) Supreme Court Orders on the Right to Food: A Tool for Action, The Right to Food Campaign, October

Roy, Aruna; Dreze, Jean and Dey, Nikhil (2007) 'The Right to Transparent Governance', Combat Law 6.2: 27-36

Roy, Aruna; Singh, Shanker and Dey, Nikhil (2006) 'Making Truth Powerful', IIC Quarterly 33.2:97, Autumn

Schedler, Andreas (1999) Conceptualizing Accountability in the Self-restraining State: Power and Accountability in New Democracies, London: Lynne Rienner

Smulovitz, Catalina and Peruzzotti, Enrique (2000) 'Societal Accountability in Latin America', Journal of Democracy 11.4

Swaminathan, Madhura (2000) Weakening Welfare: The Public Distribution of Food in India, New Delhi: Left Word

Website: http://delhigovt.nic.in/dept/food/fpds4.asp (accessed 1 November 2006)

Website: http://fcamin. nic.in (accessed 1 November 2006)

World Bank (2003) World Development Report 2004: Making Services Work for Poor People, Washington DC: World Bank 